\title{
Home Environment as A Predictor of Academic Performance of Pupils with Learning Disabilities in Buea, South West Region of Cameroon
}

\author{
Esonwo Emeaka Francisca \\ Department of Educational Psychology, \\ University of Buea, Cameroon
}

\author{
Payne Rosaline Mezoh \\ Government Bilingual High School \\ (GBHS) Limbe, Cameroon
}

\section{ABSTRACT}

The study sought to examine home environment as a predictor of academic performance for children with learning disabilities in the Buea Municipality, South West Region of Cameroon. The main was to find out the effect of home environment on the academic performance of children with learning disabilities. The study design was a survey. The study population was made up of the pupils of the three selected primary schools in the Buea municipality in the South West Region of Cameroon. The purposive sampling technique was also used to select the sample for the study. And the sample was 50 pupils with learning disabilities. Data was obtained through the use of a written exercise for the learners with learning disabilities. Data were analysed using an Epi? Data and findings were presented in frequencies, and proportions. Multiple Responses Analyses was also used for the grounding of concepts that emerged from the open-ended questions. The Chi-Square test of equality of proportions was used to compare proportions for significant difference. The relationship between conceptual components was assessed using Spearman Rho correlation test. Findings from the study indicated that there was a significant relationship between home environment and academic performance of children with learning disabilities. This means that for persons with learning disabilities to perform academically well in school the home factor must be taken into consideration such as parents' socio-economic factors, parental involvement, parents' level of education and home location.

KEY WORDS: Home Environment, Academic Performance and Learning Disabilities

\section{INTRODUCTION}

African family plays an important role in the life of a child. The link between school and home cannot be over emphasized. This however has been misconceived by many African families. To some, the education of the child is so much the responsibility of the teachers and not them As such the researcher was not aware of the fact that children and especially those with learning disabilities could only do well in school if their parents were greatly involved in their study by following them up at home after school. There are many key factors in the home that enhance the academic performance for children with learning disabilities such as parental involvement, parental status, academic and financial background, and television viewing which is one of the main activities for children in the home. Researching on the home environment, as a predictor of academic performance for children with learning disabilities, the researcher carried out sensitization of parents, teachers and pupils on the cooperation which need to take place among teachers and parents before their children with learning disabilities can be successful in school. It was from this stand point view that the researcher sought to carry out a study on the home environment as a predictor of academic performance for children with learning disabilities.

\section{Background of the study}

The history of learning disabilities can be traced as far back as April 6, 1963, when Professor Sam Kirk and others coined the term learning disabilities at a meeting of parents and professionals in Chicago. The effort began in the elementary schools and was later extended to high schools. It continues to expand today, as more special programs for post-secondary students and adults with disabilities are developed. 
The study of learning disabilities, however, started long before 1963 (Hammill, 1990; Weiederholt, 1974).During the 1920s and 1930, Samuel Orton, a specialist in neurology, developed theories and remedial reading techniques for children with severe reading problems, whom he called 'dyslexic' and believed to be brain -damaged. In the 1930s, Helen Davidson studied letter reversals-writing some letters [such as b d q and g] back words, a problem consistently observed with many pupils with learning disabilities (Davidson, 1934, 1935). In the 1930s and 40s, Sam Kirk, who worked at the Wayne helped to develop a set of word drills such as A B C D and other teaching procedures he referred to through-out his career. In 1961 he and his colleagues published the Illinois Test of Psycholinguistic Abilities (ITPA) which sought to identify individual's strengths, weaknesses, learning styles, and learning achievement .This test was used for many years to identify pupils with learning disabilities. Also in the 1960s, Marianne Frostig developed materials designed to improve pupil's visual perception, which is the ability to understand information that is seen. Her notion was that if visual perceptual skills were enhanced, reading abilities would also show improvement (Frostig, 1978).

The 1970s saw the field of learning disabilities embroiled in heated debate, and at the heart of the controversy was what approach for treatment of learning disabilities was most effective. In what was called the 'process/product debate', one group promoted instruction directed at improving pupils perceptual abilities to improve their academic skills (for example explicitly teaching pupils to read) as the best approach. The dispute was resolved when (Hammill\& Larsen's (1974) research analysis showed that perceptual approaches were seldom effective in teaching academic skills but direct instruction techniques do not make a difference (Hammill\& Larsen, 1974)

Byoung-suk (2012) stated that children need safe, healthy and stimulating environment in which to grow and learn. In recent decades, there has been a proliferation of studies on the empirical aspect of the home influence on the development of children, and trends have emerged which analyze the effects of household structural and dynamic indicators on pupils with learning disabilities (Xia,2010).Result shows that home socio-economic level (Dear, McCartney\& Taylor,2009, Gil,2011,Liuand Lu,2008; Part,2008), its typology characteristic (Burnett \&Farkas, 2003; Gennetian,2005), a suitable home environment (Barkauskiene,2009;Bodovski and Youn,2010;Campbelland Berne ,2007;Ghazarian\& Buehler,2010;Khan,Haynes, Armstrong, and Ronher,2010), parents positive outlook on education, their active involvement in it (Fiouri\& Dumas, 2009. Sirvani, 2007.Mo\& Singh, 2008) and television viewing. The effect of television viewing in the home environment and its relation to academics has been studied with controversial result (William, Haertel, \&Haertel, 1982), expectations regarding their children's academic performance are factors affecting the academic development of the vast majority of children. This influence is even more relevant for pupils with complex results (Williams, Haertel, and Haertel, 1982). The effect on academic performance ranges from largely significant to insignificant and further research in this area is warranted to support past findings.

Many theories have been written to support the fact that the home environment is a predictor of academic performance for children with learning disabilities. Family environment and their immediate surroundings isuch as the family background of education, the financial status and the activities done at home for example television programs makes up the total environment that bring together physical, social and organizational components. Ecological psychologist Roger Barker (1968) described such complex environment as "behavior settings". Abraham Maslow has been considered the father of Humanistic Psychology. Maslow's theory (19081970) based on the notion that experience is the primary phenomenon in the study of human learning and behavior. He placed emphasis on choice, creativity values, self-realization, all distinctively human qualities. For him, development of human potential, dignity and worth are ultimate concern. $\mathrm{He}$ is famous for proposing that human motivation is based on hierarchy of needs the lowest level of needs are physiological and survival needs such as hunger and thirst. Further level includes belonging and love, self-esteem and self-actualization. From Maslow's perspective, the drive to learn is intrinsic. The purpose of learning is to bring about self-actualization, and the goals of educators should include this process. Learning contributes to psychological health. From Maslow's notion, for pupils to effectively achieve academically, especially those with learning disabilities, the basic needs beginning from the home 
must be met. This could be love from parents, which makes the children feel belonging, provision of their basic school needs and above all, the concern of the teacher towards the pupils with learning disabilities. From Maslow perspective, the home environment should be a place where the essential needs of children with learning disabilities is provided without discrimination so that their self-esteem rises and as such they are able to attain high academic performance. This is done through parental involvement in children's education.

Lev Vygotsky's theory of Social Interaction plays a fundamental role in the development of cognition. Vygotsky (1978) states; "every function in the child's cultural development appears twice". That is, on the social level, and later, on the individuals level, First between people (inter-psychological) and then inside the child (intra-psychological). Again Vygotsky's is of the idea that the potential for cognitive development depends upon the "Zone of Proximal Development (ZPD)"; a level of development attained when children engage in social behavior. Full development of the ZPD depends upon full social interaction. The range of skill that can be developed with adult guidance or peer collaboration exceeds what can be attained alone. Pupils with learning disabilities, according to Vygotsky, can only be successful academically if there is collaboration between parents, teachers and peers. That is, parents must follow up their children after school and give them remedial classes.

Albert Bandura (1977), agrees with the behaviorists learning theory of social conditioning and operant conditioning; however, he adds two important ideas. Mediating processes occur between stimuli and responses; Behavior is learned from the environment through the process of observational learning. Children observe the people around them behaving in various ways. This is illustrated during the famous Bobo doll experiment.(Bandura,1961). Individuals that are observed are called models, such as parents, within the family, characters on children's, Television, friends within their peer group and teachers at school. These models provide examples of behavior to observe and imitate, for example masculine and feminine, pro and anti-social (inability to cope with the peers). Bandura, in his idea, talked of four principles (which serves as a motivating factor for learners with learning disabilities and which are both intrinsic and physical) attention, retention reproduction and motivation.

Learning disability is a concept that encompasses heterogeneous group disorders which manifest in significant difficulties in understanding, speaking, reading, writing reasoning and mathematical ability, the presumably of biological origin and related to the functioning of the central nervous system (Kavale\&Forness,2000;Lerner \& Kline, 2006). From the above perspective it is therefore maintained that learning disabilities are disorders of biological-genetic origin which are intrinsic to the individuals. However there has been a shift in focus towards environmental variables, including the home which in it claimed can enhance or minimize the negative effects of these difficulties and therefore must be thoroughly examined and taken in to consideration (Phaua, Rheula, and Schmitz, 2011; Snowling, 2007; ShurFen, 2007). Some common learning disabilities are; Dyslexia, which is a language -based disability in which a person has trouble understanding written words, it may be referred to as reading disability or reading disorder. Dyscalculia is another disability which is a mathematical disability in which a person has difficulty solving arithmetical problems and grasping mathematical concepts. Auditory and visual processing are also disorders. This is a sensory disability in which a person has difficulty understanding language despite normal hearing and vision. Dysgraphia is a writing disability in which a person finds it hard to form letters or write within a defined space. Non-verbal learning disabilities; are neurological disorder which originates in the right hemisphere of the brain, actually cause problems with visual-spatial, intuitive, organizational, evaluative and holistic processing. Dyspraxia; this disability affects motor skills development. Children who have dyspraxia typically exhibit difficulties with both fine and gross motor skills. They also find it difficult to properly execute large movements, such as jumping and running, resulting in clumsiness. Children with dyspraxia may also have difficulties with language, vision and perception (Shey, 2016).

\section{Statement of the Problem}

For most children, interior of the home and its immediate surrounding are the first environment they are exposed to throughout their early years. This is because young children, spend a majority of their time in the home surrounded by all environmental factors. It has been noted from literature review that the home 
environment of children with learning disabilities has not been taken into cognizant for the past years especially in developing countries including Cameroon. As such children with learning disabilities are often seen left behind as their peers continue in education. This can be due to the lack of cooperation between parents and teachers. Also, due to the poor financial status of some parents and their poor educational background, children with learning disabilities often see themselves as children who cannot achieve as their peers in education. The type of television programs that parents encourage their children to watch at home in fact influence the academic performance of children with learning disabilities. Good teaching programs like words building enhance the children's learning (children with learning disabilities) and can help them to achieve in education just like their peers without learning disabilities. While on the other hand, programs that do not involve cognitive abilities in the area of academic can reduce the children's chances to achieving academically. It is against this backdrop that the researcher seeks to investigate the impact of home environment on the academic performance of children with learning disabilities. Thus, clarifying the relationship between the home environment and academic performance

\section{Objectives of the Study}

- To investigate the extent to which family socioeconomic status can act as a predictor of academic performance for children with learning disabilities.

- To find out the extent to which parental involvement in their children's education influences the academic performance for children with learning disabilities.

\section{CONCEPTUALIZING ENVIRONMENT AS A PREDICTOR OF ACADEMIC PERFORMANCE AMONG STUDENTS WITH LEARNING DISABILITIES}

Home Environment is the surroundings, where one live. According to Anene, (2005), environment is the aggregate of all internal and external conditions affecting the existence, growth and welfare of organisms? It is an influence an individual came in contact with after the hereditary has been through the gene plasma. Anene explained that environment can be divided into physical, social and abstract environment. Physical environment is the objects or materials found in the home, school or community. It also includes the people like parents, siblings and peers (Anene, 2005). Sheal so explained that the social environment is the social life, societies and club affecting the individual.

Abstract environment is the reactions, feedback and the responses received on interactions with others. The author further explained that environment can also be classified as urban or rural environment. The focus of this study is on the home environmental factors affecting the academic performance of the students. This therefore, entails the objects, materials, parents, siblings, peers and social life that exists in the home in which the students find himself/herself. All the variables in the home that affect a person's existence, behavior and performance constitute the home environmental factors. Academic Performance on the other hand is the outcome of education; it is the extent to which a student, teacher or institution has achieved the educational goals. According to Bossaert, Doumen,Bugse and Verschuerenc (Bossaert, Doume, 2011), academic performance is commonly measured by examination or continuous assessment; however, there is a general agreement on how it is. It is usually a place in which an individual or a family can live and store personal property. (Magnuson, 2007) pointed out that parents academic socialization is a term describing the way parents' influences student's academic achievement by shaping students skill, behaviors and attitude towards school. He further explained that parent's influences student through the environment and discourse parents have with their children. This means that academic socialization can be influenced by parent's social economic status. Thus highly educated parents tend to have more stimulating learning environments. (Ajila, Otutola, 2000), stated that parent of all classes realized the importance of education. They also pointed out that different families create environment that influences children's intellectual growth and educational motivation in different ways. The function of the family among others includes rearing, protecting and educating the children and such function can be performed in the home, thus a home is an essential agent of education.

Home environnements influence adolescents' aspiration. The social upbringing of the child begins from home (family). It is the home that makes the child to identify himself with the society, culture, 
religion or social class. Thus the home continues to exercises a strong influence over the child's live and academic performance in the school. It has to be noted that homes differ in terms of their significances in the social orders. For instance, some have more prestige, money etc. while some have wider experience and knowledge of how to operate within the society or school environment.

Anene, (2005) stated that the home is the single most significant environmental factor in enabling children to develop the trust, attitude and skills that will help them to learn and engage positively with the world- a process that starts at birth, if not before. It is the foundation from which babies and young children and youths can grow to achieve their full potential. Good home learning environment provides the love, security, simulation, encouragement and opportunities that help children to flourish. The quality of parentchild relationship is fundamental to children's longer term development. Warmth, encouragement and an absence of hostility are key element in positive home environment.

Nanalee, (1997) pointed out that as children grow beyond babyhood, a positive home learning environment provides social interaction, attention and activities which promote the development of positive attitudes to learning, as well as the acquisition of physical, intellectual, language, social and emotional skills. The amount that parents talk to babies and young children and the way they talk to them have been shown to have a direct positive impact on children's linguistic and intellectual ability. At the age of 3 and 10 parents can provides the building blocks for literacy and cognitive development by; chatting as much as possible during normal daily life, using a wide vocabulary praising rather than criticizing, talking to children about things, using language with a high information content, giving children choices rather than simply directing them, listening and responding to what children say. Research has established that parents' socio-economic background, including education and income, has a substantial impact on children's outcomes. Ample evidence also documents the influence of parenting behaviors on children's development from babyhood to late adolescence. It is not out of place to imagine that the type of family, parents' level of education and their socioeconomic background can have possible effects on the academic performance of children in school. Again Parents' social economic status, which was conceptualized as parents' education, parents' income and parents' occupation, is linked to academic performance. The figure shows that academic performance is dependent on parents' social economic status. That is students from high social economic backgrounds will perform better than their counter parts from low social economic backgrounds as discussed. This is supported by Dills (2006), and Owens (1999). It is also in line with Hansen and Mastekaasa (2006), who argued that according to the cultural capital theory one could expect students from families who are closest to the academic culture to have greatest success.

Education being one other major means of providing an opportunity in life and belong to a suitable social class, modern Cameroon family now plays crucial roles in the performance of children in school. It's widely recognized that many factors are involved in child's academic achievement such factors as parental education level, occupation, income, social class and type of parenthood for instance the socio-economic characteristics of the family in school. They have a bearing also on the duration of his stay and achievement at school. The type of family and level of parents education and their socioeconomic status influence the choice of school they place their children. Hill, (2004), pointed out that socio economic status of parents has some influence on the academic performance of children.

Children from families with low socio-economic status are at a greater risk of hunger, homeless, sickness, physical and mental disabilities, violence, teen parenthood, family stress and educational failure. Student from low socio economic background that encounter these environmental factors are four times more likely to have learning disabilities than students from high socio economic background while a combination of these environmental factors accelerate academic success. A student, who has not eaten for days and has clothes that do not fit, cannot maintain focus in a classroom. Anene, (2005) argues that students from high social economics status compared to students from low social economic status families that students coming from low socioeconomic background are not provide the same tools as the students from wealthy families, they are entering schools already behind those not living in similar conditions. Similarly it is believed that factors such as malnutrition lack of motivation in homes, spousal violence, and single parents as well as impoverished 
home environment affects the development of intellectual ability negatively (Mario, 2006). This means that students from low socio-economic backgrounds tend to be below or just an average in their intellectual development particularly when this phenomenon is accessed in terms of score or test.

Chopra (1969), of Lucknow University studied the relationship between socio-economic background and performance. It was found that higher socioeconomic group pupils were significantly higher than those of the pupils from the middle and lower socioeconomic group. This study revealed that there is positive relationship between socio- economic background and performance in English, mathematics and science. Goswami (1982), found that in both urban and rural areas, the upper socio- economic status group has done significantly better than the lower socio-economic group in the performance tests of science, languages and humanities. Rothman's (2003), analysis revealed that within the same school, a pupil who comes from a higher socio-economic group will achieve better test results than a pupil from a lower socio-economic group. In Britain, according to a recent report by the United Kingdom Government's Social Exclusion Unit (2004), a child born into the bottom social class is still more likely to leave school with no qualifications, to live in relative poverty and to die younger than their peers born into the professional classes.

Sirin (2005,) explains, "Methodological Characteristics, such as the type of socioeconomic status(SES) measure, and student characteristics, such as pupil's grade, minority status, and school location, moderated the magnitude of the relationship between SES and academic performance." The relationship is still clear and strong enough, however, to permit statements such as the following: "Socio-economic status differences in children's reading and educational outcomes are ubiquitous, stubbornly persistent and well documented" (Aikens and Barbarin, 2008). The relationship between SES and academic performance is due to a complex interaction of a number of variables, it appears to be generally accepted that SES impacts to a considerable extent on various aspects of students' learning experiences. Meeuwisse, Severiens and Born (2010), examined the interaction of multiple variables in pupils' decisions to withdraw from higher education. They support the general theme that emerges in all of the studies reviewed herein: The interplay of variables that characterizes the investigation of SES and aspects of pupil' behavior, choices and outcomes is tremendously complex.

Parental involvement is also another area where research had been conducted .Good parenting styles such as checking of the pupils books after school and teaching the child how to read can greatly improve on the child performance. Baumrind (1971,1996) believes that parents should be neither punitive nor aloof rather they should develop rules for children, while at the same time being supportive and nurturing. She and others after hundreds of research studies came out with four main forms namely [authoritarian parenting which restrictive and punitive, authoritative which encourages children to be independent but still places limits and controls on the actions ,neglectful parenting in which parents are uninvolved in their children lives and indulgent ,parenting in which parents are highly involved with their children but place far limits or restrictions on their behavior.

Basu and Chaudhary observes that the extent of relationship in various studies have been found to vary between low to moderately high. A Metaanalysis of 47 such studies by Rothbaum and Weiz (1994) attempted to account for this discrepancy. They concluded that the parental impact on school behavior is not homogenous affair, but closely intertwined with a number of demographic and cognitive factors. Lack of awareness and control of these variables have led to misleading findings in many of these studies conducted in this respect. Parenting style and school achievement was as high as 0.39 . Student's perceptions of parental expectations also correlated with achievement. Mayuri (2003), designed a study to find out the school factors that affect academic achievement of the school children studying in class IX and X. The sample consisted of 120 children (60 each from class IX and class X) and 40 teachers from a residential school of Hyderabad city. One of the key findings of this study was that family factors like parental aspirations and socioeconomic factors had an effect on the academic achievement of the school children.

Farmer (1990) observed that expectations by significant others in the environment, viz., teachers, parents and peers, enhanced academic achievement and career motivation of learners. Bandura (1997), notes that parents contribute to their children 
intellectual growth in a variety of ways, including preparing children for the school, placing value on education, conveying beliefs in their children scholastic ability, setting standards for them, establishing regular work habits for them, encouraging language development and comprehension through reading, keeping track of academic progress, rewarding their efforts, and supporting teacher related functions.

\section{Parental involvement}

It has been found that when parents are actively involved in the academic activities of their children through class visits or helping with class activities, the children behavior and basic skills improve (Maroon, 1988). Dautscher and Ibe (2003), carried out a study to examine the role of parental involvement on child's academic performance. They assessed various types of parental involvement, viz., volunteering, home involvement, attending parental classes, school political involvement, talking to staff and talking to teachers. Approximately 400 students of 7 th through 11 th grade were included. The overall results indicated that those who went to the parent seminars (classes) or were more involved in the academic activities of children (such as checking children's planner, talking to child at home about school related topics, or engaged in educational activities outside of school), had children who performed better in various subjects or had better grades. Parental participation in school work may range from class room visits to more active participation in tutoring, text book evaluation and staff evaluation (Irvine, 1988). Taylor, Ivora and Wilson (1995) investigated the relationship between parental influences and academic outcomes for African American students. Their results indicated that parental involvement significantly predicted academic performance.

Dhingira and Manhas (2009) explored the relationship that exists between parental interaction and attitudes of teachers with academic performance of school going children. The sample comprised of 200 under achievers studying in class 4-6 grade, failing to perform satisfactorily for no apparent reason. Besides the students, their parents $(\mathrm{n}=200)$ and teachers $(\mathrm{n}$ $=189$ ) were also included in the study. The results revealed that parent child interaction and teacher attitudes significantly influenced academic performance. In a similar study, Sidhu and Gill (1988) found that class room scores were low where there were low parental motivation and sharing of parental work with the children.

At the same time, high performance has been noted among children whose parents took active interest in the academic activities of their children. It has also been reported that children performed better in schools where teachers rated parents as actively involved in school activities (Baker \&Soden, 1997). Parental involvement and encouragement are important influences on academic success which increases the likelihood of young children ultimately graduating from high Schools (Howel\&Frese, 1982). It has also been observed that parental involvement results in better relationship between school and families (Epstein, 1984). Dornbush (1994) observes that parental guidance and encouragement of academic activities increase the likelihood that children will be moving in the right direction in academics. Estrons et al. (1986) have found that high school dropout, low parental monitoring of children social activities, and low discussions with parents are associated with low academic achievements.

Although several studies in U.S.A indicate that there is a substantial positive relationship between parent's involvement and their children's academic success, there are also studies which found a negative relationship or no significant differences between experimental and control groups (e.g., Ryan, 1964; Morrow, 1982). Inconsistencies in the research findings can be explained on the basis of differences in methods of data collection and research designs used. Some researchers have studied the relationship between parental involvement and child's school success using direct observation (Arbuckle \& Mackinnon, 1988), surveys and questionnaires, or both (Edward \& Warring, 1999). Other investigations have been known to make use of traditional experimental design to compare students ${ }^{\text {ee }}$ performance across randomly allocated groups (Woods, Bernard \&Tesselle, 1974). Differences in the outcome measured also may have been another source of discrepancy. For example, a variety of dependent variables have been reported in studies on parental involvement (e.g., reading achievement: Epstein, 1987; 1991; math achievement: Davis, 1993; and perceptual skills training: Garrison, 1977). However discussions of the findings and conclusions do not always take into consideration certain important factors that can affect the validity of research findings such as the reliability of scales and tests. In a more 
recent analysis of this issue, Mattingly et al. (2002), reviewed a total of 41 studies described as "evaluations" of parental involvement programs. They concluded that there was little evidence to support the efficacy of parental involvement to improve student's performance

\section{Child's time use after School}

Children spend their time in different ways after coming home from school. These include play, television viewing, etc. Most children, especially in urban centers, spend a great deal of time in television viewing. Too much of television viewing has been associated with low academic performance. For example, Singer and Singer (1990) observed that excessive watching of television leads to reduced mental effort and shallow information processing among children. Also, excessive viewing of television among pre-scholars"e has been correlated with less elaborate make believe play. In older pre scholars, it is found to be associated with lower creativity scores.

The influence of family educational climate is defined by the amount and the style of help that children receive from the family; that is determined by elements of the family context, like dynamic of communication and effective relationships, attitudes towards values, expectations etCeteral (Diaz,2004) .Along these same lines,Marchesi and Martin (2002) reported that parental expectations have a notable influence on academic performance or results, even when controlling for initial knowledge and socioeconomic context Castejon and Perez (1998), found indirect relationships with performance from the pupils perception of how much importance his or her parents assign to study at home.

The literature review on the parent level of education have showed that, the education that children receive is much dependent on the education that their parents received when they were children .Research shows that the literacy of their parents strongly affects the education of their children. Teale found in his studies that 'children experience literacy primarily as a social process during their school years.'(Teale, 1986) parents strongly affect this social learning process because they are the biggest influence at this early stage in the children lives. One of the reasons why it strongly affected their children's education is because' parents who have gone beyond a high school education are found to be more involved with their infants and children than those who did not finish high school. Many less educated parents have more unmanaged stress in their lives, and this stress interferes with ability and opportunity to interact with their child (Sclafani, 1988). Typically ,parents who have finished high school and gone on to receive additional schooling understand the pressures and stress of school and are more equipped to handle them with their children when they go through school.

Parent who have obtained further educational opportunities also have less stress in their lives because they most likely making more money while spending less time making that money than those who, unfortunately, have not been able to finished high school for one reason or the other. It is unfortunate that less educated parents are less involved in their children's education process because research repeatedly demonstrates that schools and districts do better when parents are engaged as equal partners in the decision making that affect their children schools. Only through this richer level of engagement will parents and the public at large better understand their vital connection to quality public education (Glickman 229). Parents with less education do not participate as often in their children's education to some effects because they do not realize the importance of interaction with school and they are probably intimidated, just like they were in high school.

\section{Educational Level of Parents}

It has been noted that children of educated and affluent parents generally have more opportunities for achievements. Educated parents encourage their children to have relationship with peers who share their values, especially values of achievement (Wentzel\& Feldman, 1993; William \&Rudin, 1993).

Parents, who are better educated, tend to communicate better with their children when compared to parents who are less educated. Educated parents interact with the children at home by way of reading with them, conversing with them and directly teaching them required social skills. All these help to improve the knowledge base of the children and also their performance at school (Flood \& Anders, 2006). Devi and Kiran (2002), designed a study to find out the family factors associated with scholastic backwardness among secondary school children.

Their sample consisted of 100 low achieving students ( 50 boys and 50 girls) of 9th and 10th grade, drawn from ten private schools selected from all the five zones of Hyderabad city in India. Their study revealed 
that low educational status of parents, large family size, and low parental involvement and encouragement were the major family factors associated with scholastic backwardness. Mayuri and Biliquis (1999), conducted a study on 467 rural children in the age range of 6-12 years to investigate the correlates of intellectual abilities in them. The findings of the study revealed that socio-economic variables, viz., parental education and occupation, were the significant predictors. Sunita and Mayuri (1999), in another study, examined the role of socioeconomic status, interests and adjustment in the academic achievement of children. The study revealed that educational and occupational status of the family, small and nuclear family, as well as support and encouragement from parents and siblings, significantly enhanced the academic achievement of school children. It has been noted that there is a positive association between assistance with homework and children's academic achievement, regardless of the source of assistance in the family. But this assistance was found more often among parents who were of high educational levels. (Hassan, 2003).

The national center for education statistics (NCES) in U.S.A. conducted a study in 1998 to find out the health status of kindergarten children in relation to the risk status of the child's family. The four risk indicators were: low maternal education, family on welfare, one parent in the home, and a parent speaking a language other than English at home. The results of the study indicated that the children in families with no risk factors were more likely to be in excellent health $(59 \%)$ when compared to those with one $(44 \%)$ or two or more risk factors $(37 \%)$. Twenty nine percent of the children from high risk families were in fair or poor health compared to $10 \%$ of those in no risk families. They also noted that children from lower risk families were more likely to engage in positive social behaviors such as making friendship and helping their class mates. Children from higher risk families were less likely to have positive attitudes towards class room activities, pay attention or show eagerness to learn, and were more likely to display anti-social behaviors such as arguing and fighting, which are associated with poor performance in school (Flood \& Anders, 2005).

There are several research reports which indicate that maternal characteristics are important determinants of academic achievement. There are several research reports which indicate that maternal characteristics are important determinants of academic achievement (Emmon, 2005; Majuribanks, 1996). Mothers who are educated have higher self-esteem and have children who received high test scores (Emmon, 2005). Also, mothers who delay child bearing have been shown to provide more cognitively stimulating and supportive environment at home, which has a positive effect on school performance (Emmon, 2005; Majuribank, 1996). Mother's educational attainment has also been reported as a significant predictor of high school completion (Ekstron et al, 1986). Khan and Jembero (2002), conducted a study to investigate the influence of socio-economic status (SES) on educational and occupational aspirations of adolescents. Their sample consisted of 80 students selected from two schools in Aligar city, in India, obtained using stratified random sampling. The results of the study indicated that while the impact of socio-economic status on educational aspirations was minimal, its influence on occupational aspirations was significant. Socio-economic status was also found to affect the adolescent's aspirations indirectly through family salience. There are several research reports which indicate that maternal characteristics are important determinants of academic achievement (Emmon, 2005; Majuribanks, 1996). Mothers who are educated have higher selfesteem and have children who received high test scores (Emmon, 2005).

\section{METHODOLOGY}

The design used for this study was a survey .Survey research collected data from a few people or items considered to be a representative of the entire group. It is an ex-post factor correlation survey, because the study involved seeking opinion of the pupils in their natural setting and correlating the finding with pupils' performances in school.

\section{Population of the study}

The population was classified into three; the general population which is the population of all the pupils in primary school in the Buea municipality, the target population which consisted of all the pupils in some three selected primary schools (Government Practicing School(GPS) Molyko, Redeemer International Primary School and Catholic School Molyko) in the Buea municipality and the accessible population consisted of pupils with learning disabilities in classes four and five from the three selected primary schools in the target population. A summary of the accessible population is shown on the table below; 
Table 1: Accessible population and Sample of the Study selected.

\begin{tabular}{|c|c|c|c|}
\hline Name of School & Class & $\begin{array}{c}\text { Number } \\
\text { of Pupils }\end{array}$ & $\begin{array}{c}\text { Number of } \\
\text { Pupils } \\
\text { with LDs }\end{array}$ \\
\hline GPS Molyko & 4 & 24 & 13 \\
\cline { 2 - 4 } & 5 & 25 & 10 \\
\hline $\begin{array}{c}\text { Redeemer } \\
\text { International } \\
\text { Primary School }\end{array}$ & 4 & 24 & 1 \\
\cline { 2 - 4 } & 5 & 22 & 2 \\
\hline $\begin{array}{c}\text { Catholic School } \\
\text { Molyko }\end{array}$ & 4 & 32 & 15 \\
\cline { 2 - 4 } Total & 5 & 31 & 9 \\
\hline
\end{tabular}

Source: Total number of pupils with and without Learning Disabilities in the targeted schools and the sample from the school head office.

From the table above our accessible population was 158 pupils and our sample was 50 pupils. GPS Molyko class four, accessible population 24, sample 13; class five accessible population 25, sample 10. Redeemer International Primary School Molyko class four, accessible population 24, sample 1; class five accessible population 22, sample 2. Catholic School Molyko class four, accessible population 32, sample 15; class five accessible population 31, sample 9.

\section{Sample and Sampling Technique}

The purposive sampling technique was used to select the schools and the classes that constituted the target and accessible population respectively. Fraenkel and Norman (2000), define purposive sampling as a technique in which the researcher assumes that he/she can use his/her knowledge of the population to judge whether or not a particular sample will be representative of the study. This is done based on a previous knowledge of a population and the specific purpose of the research. In this type of technique therefore, personal judgment is used to select a sample. This method was chosen because the researcher could only work with children with learning disabilities and therefore identified Government Practicing Primary School Molyko, Redeemer International Primary School and Catholic School Molyko. Classes four and five were also selected purposively firstly because it is at these classes that words building are completely mastered. Secondly, remediation programs implemented at this level will be effective if these pupils are identified.

The pupils used were gotten by checking their birth certificates in schools in order to get the pupils who were at the age 7-12 years. This was because at this ages the children who could not reason like their peers. Using documented literature on learning disabilities as well as the experience gotten from practicum and with the assistance of their class teachers the researcher also checked their note books which comprises of their writing books, spelling, mathematics and understanding and response books, and also their first and second term results through the reading exercises spellings mathematical test. This was done after the researcher had observed the pupils for some weeks. Thus a purposive sampling technique was used as only those selected by the class teachers and the researcher were involved. Thus those who had difficulties in these areas and were below average during the first and second term examination were said to be pupils having learning disabilities.

\section{Sample description of school}

Table 2: Distribution of sampled school

\begin{tabular}{|c|c|c|}
\hline Schools & Frequency & $\begin{array}{c}\text { Percentage } \\
\text { of pupils } \\
\text { per school }\end{array}$ \\
\hline $\begin{array}{c}\text { GPS Molyko } \\
\begin{array}{c}\text { International Primary } \\
\text { School }\end{array}\end{array}$ & 6 & 12.0 \\
\hline $\begin{array}{c}\text { Catholic School } \\
\text { Molyko }\end{array}$ & 27 & 34.0 \\
\hline Total & $\mathbf{5 0}$ & $\mathbf{1 0 0 . 0}$ \\
\hline
\end{tabular}

Three schools were sampled for the study among which Redeemers International $12.0 \%$ (6) a lay private school, Catholic School Molyko 34.0\% (17) a confessional school and GPS Molyko 54.0\% (27) a government school. Percentage represents the percentages of the pupils selected from the three schools that the researcher used.

\section{Gender}

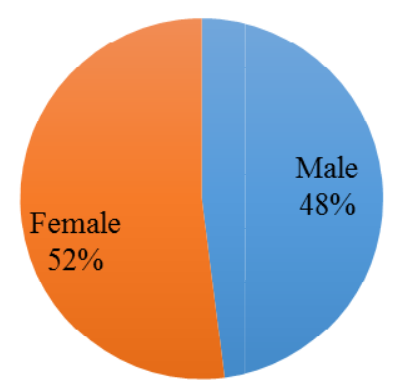

Figure 1: Sample distribution by gender 
Both the male and the female were well represented in the sample whereby they were (24) $48.0 \%$ of the male and (26) $52.0 \%$ for the female. Children with learning disability were sampled in class three with a proportion of (4)8.0\%, class four (26) $52.0 \%$ and class five $(20) 40.0 \%$. The sample population for parents were 10 in number which were randomly selected from the schools concern on the day the researcher when to the filed to administer her questionnaire the parents who happened in school were interviewed and their responses were taped, which were later on written down by the researcher.

\section{Validation of Instruments}

To ensure face validity of the instrument, the researcher scrutinized the items, checking the clarity and appropriateness of language and clarity. corrections were effected and re-corrected, where the supervisor accepted the questionnaire and interview guide were considered to have attained faced validity. To evaluate the content validity of the instrument, the researcher scrutinized the questionnaire and interview guide and checked the relevance of items to the objectives of the study. Existing literature on the area of learning disabilities, home environment academic performance was used to check construct validity. To reduce threats to internal validity all the pupils who took part in the study were pupils with learning disabilities in classes four and five from the three schools selected with their ages ranging from 712yeas.

\section{Reliability}

The test-retest method involved administering the same test twice to the same group after a certain time interval has elapsed. It showed the level of achievement and internal consistency of the instrument over time. A reliability coefficient at 0.05 was used to calculate the internal consistency of the instrument and to show the relationship and consistency between the two sets of scores obtained from the two groups. To ensure that the research instrument measured consistently what they were designed to measure, the instruments were trial-tested using 20 pupils in the Buea municipality. These pupils where no longer used during the main study. The data collected was tested for reliability using the Cronbach Coefficient Alpha Method.

\section{Reliability analysis for pilot study}

\section{Table 3; Reliability analysis for the pilot study}

\begin{tabular}{|c|c|c|c|}
\hline Conceptual components & Cronbach's Alpha & $\mathbf{N}_{\text {cases }}$ & $\mathbf{N}_{\text {item }}$ \\
\hline Parental attention & 0.648 & 5 & 7 \\
\hline Parental encouragement & 0.512 & 5 & 9 \\
\hline Parental communication & 0.568 & 5 & 4 \\
\hline Location of house & 0.650 & 5 & 6 \\
\hline Emotional development & 0.203 & 5 & 6 \\
\hline IVM & 0.705 & 5 & 32 \\
\hline
\end{tabular}

At pilot test, the internal consistency assumption was violated only for the component emotional development. It was assumed that a child could perceive his emotional development based on one or more of the indicator differently from other indicators and simply language restructuring for clarity was made. However, conceptually, high Alpha value was not expected for this component. This trend of reliability therefore applied to the real study or final study.

\section{Methods of data processing and analysis}

Open-ended questionnaire and interview items were analyzed using the process of thematic analysis whereby concepts or ideas were grouped under umbrella terms or key words. As for the quantitative data, a pre-designed EpiData Version 3.1 (EpiData Association, Odense Denmark, 2008) database which has in-built consistency and validation checks was used to enter the data. Further consistency, data range and validation checks were also performed in SPSS version 21.0 (IBM Inc., 2012), to identify invalid codes. 
Data were made essentially of categorical variables and they were analyzed using frequency and proportions and Multiple Response Analysis to aggregate responses within conceptual components. Reliability test was performed to assess the internal consistency of responses using Cronbach Alpha reliability analysis. Chi-Square test was used to compare proportions for significant difference. Composite variables were generated to aggregate score within conceptual components and the effect of parental attention, parental encouragement, parental communication and home location on the emotional development of pupils was measured using Pearson's correlation test because all the variables violated the normality assumption at the 0.05 level (Kolmogorov-Smirnov tests for normality: $\mathrm{P}<0.05$ ).

\section{F FINDINGS}

\section{Academic Performance of Children with Learning Impairment}

Table 4: Distribution of academic performance of children with learning disabilities

\begin{tabular}{|c|c|c|c|c|}
\hline \multirow{2}{*}{$\begin{array}{c}\text { Academic } \\
\text { performance }\end{array}$} & \multicolumn{2}{|c|}{ Average first sequence } & \multicolumn{2}{c|}{ Average second sequence } \\
\cline { 2 - 5 } & $\mathbf{N}$ & $\mathbf{\%}$ & $\mathbf{N}$ & $\mathbf{\%}$ \\
\hline $0-49$ scores & 50 & 100 & 47 & 94.0 \\
\hline $0-59$ scores & 0 & 0.0 & 1 & 2.0 \\
\hline $60-79$ scores & 0 & 0.0 & 2 & 4.0 \\
\hline Total & $\mathbf{0}$ & $\mathbf{0 . 0}$ & $\mathbf{5 0}$ & $\mathbf{1 0 0 . 0}$ \\
\hline
\end{tabular}

From the table, all the pupils $100 \%$ (50) during the first sequence examination had averages ranging from $0-49$ and no pupil 0\% (0) had an average above 49-79. Again during the second sequence 94.0\% (47) pupils had scores ranging from $0-49$ and $2 \%$ (1) had a score that fell within the scores $0-59$. Furthermore, $4 \%$ (2) pupils had scores within the range of 60-70.

To what extend does family socioeconomic status affect the academic performance of children with learning disabilities?

Table 5: Socio-economic status of family as perceived by children with learning disabilities.

\begin{tabular}{|c|c|c|c|}
\hline Socio-economic status of family & Agree & Disagree & $\mathbf{N}$ \\
\hline My parents are able to pay my school fees in time $1=6-170$ & $88.0 \%(44)$ & $12.0 \%(6)$ & 50 \\
\hline I always go to school with all my books & $82.0 \%(41)$ & $18.0 \%(9)$ & 50 \\
\hline My home environment is very conducive for me to study & $82.0 \%(41)$ & $18.0 \%(9)$ & 50 \\
\hline $\begin{array}{l}\text { My family structure is such that my parent easily provides me with } \\
\text { good health care. }\end{array}$ & $74.0 \%(37)$ & $26.0 \%(13)$ & 50 \\
\hline $\begin{array}{l}\text { My parents' social status in the society is such that they constantly } \\
\text { instruct me on how to study. }\end{array}$ & $66.0 \%(33)$ & $43.0 \%(17)$ & 50 \\
\hline $\begin{array}{l}\text { My parents culture of reading and studying has been inculcated in } \\
\text { me }\end{array}$ & $64.0 \%(32)$ & $36.0 \%(18)$ & 50 \\
\hline $\begin{array}{l}\text { My parents level of education has greatly influence my studies in } \\
\text { school. }\end{array}$ & $58.0 \%(29)$ & $42.0 \%(21)$ & 50 \\
\hline MRS & $73.4 \%(257)$ & $26.6 \%(93)$ & 350 \\
\hline
\end{tabular}

In aggregate, a greater majority of children with learning disabilities with a proportion of $73.4 \%$ (257) agreed to the characteristics of socio-economic factors as being influential on their academic performance. In detail, $88.0 \%$ (44) agreed that their parents are able to pay their school fees on time, $82.0 \%$ (41) agreed that they always go to school with all their text books and the same proportion agreed that their home environment are very conducive for them to study. Also, $74.0 \%$ (37) of the children agreed that their family structures were such that their parents easily provide them with good health care, 66.0\% (33) agreed that their parents' social status in the society is such that they constantly instruct them on how to study, while $64.0 \%$ (32) agreed that their parents' culture of reading and studying had been inculcated in them and 58.0\% (29) agreed that their parents' level of education had greatly influenced their studies in school. 
International Journal of Trend in Scientific Research and Development (IJTSRD) ISSN: 2456-6470

Table 6: Research Question One: Socio-economic status of family as perceived by children with learning impairment distributed by background indicators.

\begin{tabular}{|c|c|c|c|c|c|}
\hline Indicators & Categories & Agree & Disagree & $\mathbf{N}_{\text {responses }}$ & Chi-Square \\
\hline \multirow[t]{3}{*}{ School type } & Government & $69.7 \%(122)$ & $30.3 \%(53)$ & 175 & \multirow{3}{*}{$\begin{array}{l}\chi 2=2.38 \\
P=0.304\end{array}$} \\
\hline & Lay private & $42.9 \%(9)$ & $57.1 \%(12)$ & 21 & \\
\hline & Confessional & $81.8 \%(126)$ & $18.2 \%(28)$ & 154 & \\
\hline \multirow[t]{2}{*}{ Gender } & Male & $69.6 \%(117)$ & $30.4 \%(51)$ & 1168 & \multirow{2}{*}{$\begin{array}{l}\chi 2=0.24 \\
P=0.624\end{array}$} \\
\hline & Female & $76.9 \%(140)$ & $23.1 \%(42)$ & 182 & \\
\hline \multirow[t]{2}{*}{ Age } & $7-9$ & $93.9 \%(46)$ & $6.1 \%(3)$ & 49 & \multirow{2}{*}{$\begin{array}{l}\chi 2=1.50 \\
P=0.220\end{array}$} \\
\hline & 10-12 & $70.1 \%(211)$ & $29.9 \%(90)$ & 301 & \\
\hline \multirow{3}{*}{$\begin{array}{c}\text { Academic } \\
\text { performance }\end{array}$} & Poor & $71.7 \%(236)$ & $28.3 \%(93)$ & 329 & \multirow{3}{*}{$\begin{array}{l}\chi 2=7.99 \\
P=0.018\end{array}$} \\
\hline & Average & $100.0 \%(7)$ & $0.0 \%(0)$ & 7 & \\
\hline & Good & $41.7 \%(5)$ & $58.3 \%(7)$ & 12 & \\
\hline \multirow{5}{*}{$\begin{array}{c}\text { Person with whom } \\
\text { living }\end{array}$} & Both parents & $84.6 \%(148)$ & $15.4 \%(27)$ & 175 & \multirow{5}{*}{$\begin{array}{l}\chi 2=41.66 \\
P=0.000\end{array}$} \\
\hline & Father & $75.0 \%(21)$ & $25.0 \%(7)$ & 28 & \\
\hline & Mother & $51.4 \%(18)$ & $48.6 \%(17)$ & 35 & \\
\hline & Relative & $66.7 \%(70)$ & $33.3 \%(35)$ & 105 & \\
\hline & Non-relative & $.0 \%(0)$ & $100.0 \%(7)$ & 7 & \\
\hline \multirow[t]{2}{*}{ Marital regime } & Monogamy & $76.6 \%(117)$ & $23.4 \%(54)$ & 231 & \multirow{2}{*}{$\begin{array}{l}\chi 2=0.00 \\
P=0.969\end{array}$} \\
\hline & Polygamy & $66.7 \%(28)$ & $33.3 \%(14)$ & 42 & \\
\hline \multirow[t]{3}{*}{ Religion } & Islam & $100.0 \%(7)$ & $.0 .0 \%(0)$ & 7 & \multirow{3}{*}{$\begin{array}{l}\chi 2=5.54 \\
P=0.062\end{array}$} \\
\hline & $\begin{array}{c}\text { Traditional } \\
\text { relioion }\end{array}$ & $61.9 \%(26)$ & $38.1 \%(16)$ & 42 & \\
\hline & Christianity & $74.4 \% .(224)$ & $25.6 \%(77)$ & 301 & \\
\hline \multirow[t]{7}{*}{$\begin{array}{l}\text { Father's } \\
\text { occupation }\end{array}$} & $\begin{array}{c}\text { Farming/hunting/ } \\
\text { Fishing/Animal } \\
\text { husbandry }\end{array}$ & $73.0 \%(143)$ & $\mathbf{2 7 . 0 \% ( 5 3 )}$ & 196 & \multirow[t]{7}{*}{$\begin{array}{l}\chi 2=37.95 \\
P=0.000\end{array}$} \\
\hline & Small trade & $66.6 \%(14)$ & $33.3 \%(7)$ & 21 & \\
\hline & Business & $96.4 \%(27)$ & $3.6 \%(1)$ & $(1) \mathbf{2 8}$ & \\
\hline & Skilled worker & $87.3 \%(55)$ & $12.7 \%(8)$ & 63 & \\
\hline & Semi/unskilled & $48.6 \%(17)$ & $51.4 \%(18)$ & 35 & \\
\hline & worker & & & & \\
\hline & Student/applicant & $14.3 \%(1)$ & $85.5 \%(6)$ & 7 & \\
\hline \multirow[t]{6}{*}{$\begin{array}{c}\text { Mother's } \\
\text { occupation }\end{array}$} & $\begin{array}{c}\text { Farming/hunting/ } \\
\text { Fishing/Animal } \\
\text { husbandry }\end{array}$ & $73.3 \%(124)$ & $26.2 \%(44)$ & 168 & \multirow[t]{6}{*}{$\begin{array}{l}\chi 2=0.87 \\
P=0.972\end{array}$} \\
\hline & Trade & $71.4 \%(10)$ & $28.6 \%(4)$ & 14 & \\
\hline & Business & $69.0 \%(29)$ & $31.0 \%(13)$ & 42 & \\
\hline & Skilled worker & $76.8 \%(43)$ & $23.2 \%(13)$ & 56 & \\
\hline & Housewife & $71.4 \%(30)$ & $28.6 \%(12)$ & 42 & \\
\hline & $\begin{array}{c}\text { Semi/unskilled } \\
\text { worker }\end{array}$ & $75.0 \%(21)$ & $25.0 \%(7)$ & 28 & \\
\hline \multirow[t]{4}{*}{ Development index } & Very low & $51.0 \%(50)$ & $49.0 \%(48)$ & 98 & \multirow{4}{*}{$\begin{array}{l}\chi 2=7.90 \\
P=0.048\end{array}$} \\
\hline & Low & $81.0 \%(68)$ & $19.0 \%(16)$ & 84 & \\
\hline & High & $74.3 \%(78)$ & $25.7 \%(27)$ & 105 & \\
\hline & Very high & $96.8 \%(61)$ & $3.2 \%(2)$ & 63 & \\
\hline \multirow{4}{*}{$\begin{array}{c}\text { Father's level of } \\
\text { school attainment }\end{array}$} & Primary & $55.1 \%(54)$ & $44.9 \%(44)$ & 98 & \multirow{4}{*}{$\begin{array}{l}\chi 2=4.19 \\
P=0.241\end{array}$} \\
\hline & Secondary & $68.4 \%(67)$ & $65.5 \%(55)$ & 98 & \\
\hline & Higher & $88.9 \%(112)$ & $11.1 \%(14)$ & 126 & \\
\hline & Never been to & $85.7 \%(24)$ & $14.3 \%(4)$ & 28 & \\
\hline
\end{tabular}


International Journal of Trend in Scientific Research and Development (IJTSRD) ISSN: 2456-6470

\begin{tabular}{|c|c|c|c|c|c|}
\hline & school & & & & \\
\hline \multirow{2}{*}{$\begin{array}{c}\text { Mother's level of } \\
\text { school attainment }\end{array}$} & Primary & $\mathbf{5 9 . 3 \% ( 5 4 )}$ & $\mathbf{4 0 . 7 \% ( 3 7 )}$ & 91 & \multirow{2}{*}{$\begin{array}{c}\boldsymbol{2}=3.52 \\
\mathbf{P}=\mathbf{0 . 3 1 9}\end{array}$} \\
\cline { 2 - 5 } & Secondary & $\mathbf{7 6 . 4 \% ( 1 0 7 )}$ & $\mathbf{2 3 . 6 \% ( 3 3 )}$ & $\mathbf{1 4 0}$ & \multirow{2}{*}{} \\
\cline { 2 - 5 } & Higher & $\mathbf{8 8 . 1 \% ( 7 4 )}$ & $\mathbf{1 1 . 9 \% ( 1 0 )}$ & $\mathbf{8 4}$ & \\
\cline { 2 - 5 } & $\begin{array}{c}\text { Never been to } \\
\text { school }\end{array}$ & $\mathbf{6 2 . 6 \% ( 2 2 )}$ & $\mathbf{3 7 . 1 \% ( 1 3 )}$ & $\mathbf{3 5 0}$ & \\
\hline
\end{tabular}

The findings indicated that socio-economic status was significantly dependent of academic achievement $(\mathrm{P}<0.05)$ whereby more of those who perceived the socio-economic status of the family as not satisfactory performed well with a proportion of $58.3 \%$. Children who stayed with both the most perceived the socioeconomic status of the family as satisfactory with proportion of $84.6 \%$, followed by those who stayed with their father $75.0 \%$ while the weight was $51.4 \%$ for those staying with mother $(\mathrm{P}<0.05)$. Children whose father were doing business $(96.4 \%)$ or were skilled workers $(87.3 \%)$ higher proportion of those who perceived the socioeconomic status of their family as satisfactory $(\mathrm{P}<0.05)$. Logically, children from household with very high development index with a proportion of $96.8 \%$ had the highest proportion of those who perceived the socioeconomic status of their family as satisfactory.

To what extend does parental involvement affect the academic performance of children with learning disabilities?

Table 7: Parental Involvement as perceived by children with learning disabilities

\begin{tabular}{|c|c|c|c|c|}
\hline No & Items & Agree & Disagree & $\mathbf{N}$ \\
\hline 1 & $\begin{array}{l}\text { I often talk to my parents about what } \\
\text { I learn in school }\end{array}$ & $66.0 \%(33)$ & $34.0 \%(17)$ & 50 \\
\hline 2 & $\begin{array}{l}\text { I always work with my parent at } \\
\text { home on my school subjects }\end{array}$ & $\mathbf{7 0 . 0 \% ( 3 5 )}$ & $30.0 \%(15)$ & 50 \\
\hline 3 & $\begin{array}{l}\text { My parents often talk to me about } \\
\text { what I learn in school }\end{array}$ & $\begin{array}{l}\mathbf{6 2 . 0 \%} \%(31) \\
\text { chand }\end{array}$ & $38.0 \%(19)$ & 50 \\
\hline 4 & $\begin{array}{l}\text { My parents are always present } \\
\text { during my school PTA meetings }\end{array}$ & $\mathbf{7 0 . 0 \% ( 3 5 )}$ & $30.0 \%(15)$ & 50 \\
\hline 5 & My parents always visit our school & $68.0 \%(34)$ & $32.0 \%(16)$ & 50 \\
\hline 6 & $\begin{array}{l}\text { My parents hardly speak with my } \\
\text { school teachers concerning my } \\
\text { performance. }\end{array}$ & $62.0 \%(31)$ & $38.0 \%(19)$ & 50 \\
\hline 7 & $\begin{array}{l}\text { My parents pay my fees and buy my } \\
\text { text books on time }\end{array}$ & $78.0 \%(38)$ & $20.0 \%(12)$ & 50 \\
\hline 8 & $\begin{array}{l}\text { My parents give me a lot of house } \\
\text { chores }\end{array}$ & $40.0 \%(20)$ & $60.0 \%(30)$ & 50 \\
\hline 9 & $\begin{array}{l}\text { Even though my parents cannot assist } \\
\text { me at home, they have provided } \\
\text { somebody else to do so }\end{array}$ & $56.0 \%(28)$ & $44.0 \%(22)$ & 50 \\
\hline & MRS & $62.9 \%(283)$ & $37.1 \%(167)$ & 450 \\
\hline
\end{tabular}

In aggregate, a greater majority of children with learning disabilities with a proportion of $62.9 \%$ (283) agreed that their parents' level of involvement in their education was influential in their academic performance. Inn detail $66.0 \%$ (33) accepted that they often talk to their parents about what they learn in school. Again $70.0 \%$ (35) agreed that their parents always work with their parents on their school subjects at home. Furthermore $62.0 \%(31)$ of pupils with learning disabilities agreed that their parents often talk concerning what they learn in school.70.0\%(35) further accepted that their parents were always attending their school PTA meetings.86.0\%(34) of pupils with learning disabilities further agreed that that their parents always visit their school.62.0\% of pupils with learning disabilities again agreed that parents hardly spook to their school teacher concerning their academic performance $.78 .0 \%(38)$ of pupils with learning disabilities also accepted that their 
International Journal of Trend in Scientific Research and Development (IJTSRD) ISSN: 2456-6470 parents pay their fees and bought their text books on time. Only 40.0\%(20) of pupils with learning disabilities accepted that their parents gave them lot of house chores.Finally,56.0\%(28) of pupils with learning disabilities agreed to the fact that even though their parents could not assist them in their book work at home provided someone who assisted them.

Table 8: Parental involvement as perceived by children with learning impairment distributed by background indicators.

\begin{tabular}{|c|c|c|c|c|c|}
\hline Indicators & Categories & Agree & Disagree & $\mathbf{N}$ & $\begin{array}{l}\text { Chi- } \\
\text { Square }\end{array}$ \\
\hline \multirow[t]{3}{*}{ School type } & Government & $58.7 \%(132)$ & $41.3 \%(93)$ & 225 & \multirow{3}{*}{$\begin{array}{l}\chi 2=0.60 \\
P=0.740\end{array}$} \\
\hline & Lay private & $59.3 \%(16)$ & $40.7 \%(11)$ & 27 & \\
\hline & Confessional & $69.2 \%(137)$ & $30.8 \%(61)$ & 198 & \\
\hline \multirow[t]{2}{*}{ Gender } & Male & $65.3 \%(141)$ & $34.7 \%(75)$ & 216 & \multirow{2}{*}{$\begin{array}{l}\chi 2=0.14 \\
P=0.706\end{array}$} \\
\hline & Female & $61.5 \%(144)$ & $38.5 \%(90)$ & 234 & \\
\hline \multirow[t]{2}{*}{ Age } & $3-6$ & $81.0 \%(51)$ & $19.0 \%(12)$ & 63 & \multirow{2}{*}{$\begin{array}{l}\chi 2=0.75 \\
P=0.386\end{array}$} \\
\hline & $7-10$ & $60.5 \%(234)$ & $39.5 \%(153)$ & 387 & \\
\hline \multirow{3}{*}{$\begin{array}{l}\text { Academic } \\
\text { performance }\end{array}$} & Poor & $62.4 \%(264)$ & $37.6 \%(159)$ & 423 & \multirow{3}{*}{$\begin{array}{l}\chi 2=3.30 \\
P=0.192\end{array}$} \\
\hline & Average & $88.9 \%(8)$ & $11.1 \%(1)$ & 9 & \\
\hline & Good & $72.2 \%(13)$ & $27.8 \%(5)$ & 18 & \\
\hline \multirow{5}{*}{$\begin{array}{l}\text { Person with } \\
\text { whom living }\end{array}$} & Both parents & $68.9 \%(155)$ & $31.1 \%(70)$ & 225 & \multirow{5}{*}{$\begin{array}{l}\chi 2=41.66 \\
P=0.000\end{array}$} \\
\hline & Father & $63.9 \%(23)$ & $36.1 \%(13)$ & 36 & \\
\hline & Mother & $53.3 \%(24)$ & $46.7 \%(21)$ & 45 & \\
\hline & Relative Internatic & $59.3 \%(80)$ & $40.7 \%(55)$ & 135 & \\
\hline & Non-relative $T$ & $33.3 \%(3)$ & $66.7 \%(6)$ & 9 & \\
\hline \multirow{2}{*}{$\begin{array}{l}\text { Marital } \\
\text { regime }\end{array}$} & Monogamy & $63.6 \%(189)$ & $36.4 \%(108)$ & 297 & \multirow{2}{*}{$\begin{array}{l}\chi 2=0.10 \\
P=0.749\end{array}$} \\
\hline & Polygamy & $61.1 \%(33)$ & $38.9 \%(21)$ & 54 & \\
\hline \multirow[t]{3}{*}{ Religion } & Islam & $88.9 \%(8)$ & $11.1 \%(1)$ & 9 & \multirow{3}{*}{$\begin{array}{l}\chi 2=1.58 \\
P=0.455\end{array}$} \\
\hline & Traditional religion & $63.0 \%(34)$ & $37.0 \%(20)$ & 54 & \\
\hline & Christianity & $62.8 \%(243)$ & $37.2 \%(144)$ & 387 & \\
\hline \multirow[t]{6}{*}{$\begin{array}{l}\text { Father's } \\
\text { occupation }\end{array}$} & $\begin{array}{l}\text { Farming/hunting/ } \\
\text { Fishing/Animal } \\
\text { husbandry }\end{array}$ & $63.9 \%(161)$ & $36.1 \%(91)$ & 252 & \multirow[t]{6}{*}{$\begin{array}{l}\chi 2=7.09 \\
P=0.214\end{array}$} \\
\hline & Trade & $59.3 \%(16)$ & $40.7 \%(11)$ & 27 & \\
\hline & Business & $58.3 \%(21)$ & $41.7 \%(15)$ & 36 & \\
\hline & Skilled worker & $72.8 \%(59)$ & $27.2 \%(22)$ & 81 & \\
\hline & Semi/unskilled worker & $53.3 \%(24)$ & $46.7 \%(21)$ & 45 & \\
\hline & Student/applicant & $44.4 \%(4)$ & $55.6 \%(5)$ & 9 & \\
\hline \multirow[t]{6}{*}{$\begin{array}{l}\text { Mother's } \\
\text { occupation }\end{array}$} & $\begin{array}{l}\text { Farming/hunting/ } \\
\text { Fishing/Animal } \\
\text { husbandry }\end{array}$ & $67.6 \%(146)$ & $32.4 \%(70)$ & 216 & \multirow[t]{6}{*}{$\begin{array}{l}\chi 2=7.96 \\
P=0.158\end{array}$} \\
\hline & Trade & $66.7 \%(12)$ & $33.3 \%(6)$ & 18 & \\
\hline & Business & $55.6 \%(30)$ & $44.4 \%(24)$ & 54 & \\
\hline & Skilled worker & $78.0 \%(51)$ & $29.2 \%(21)$ & 72 & \\
\hline & Housewife & $61.1 \%(33)$ & $38.9 \%(23)$ & 54 & \\
\hline & Semi/unskilled worker & $63.1 \%(13)$ & $63.9 \%(23)$ & 36 & \\
\hline \multirow{4}{*}{$\begin{array}{l}\text { Development } \\
\text { index }\end{array}$} & Very low & $50.0 \%(63)$ & $50.0 \%(63)$ & 126 & \multirow{4}{*}{$\begin{array}{l}\chi 2=2.02 \\
P=0.569\end{array}$} \\
\hline & Low & $63.0 \%(68)$ & $37.0 \%(40)$ & 108 & \\
\hline & High & $65.9 \%(89)$ & $34.1 \%(46)$ & 135 & \\
\hline & Very high & $80.2 \%(65)$ & $19.8 \%(16)$ & 81 & \\
\hline
\end{tabular}


International Journal of Trend in Scientific Research and Development (IJTSRD) ISSN: 2456-6470

\begin{tabular}{|c|c|c|c|c|c|}
\hline \multirow{4}{*}{$\begin{array}{l}\text { Father's } \\
\text { level of } \\
\text { school } \\
\text { attainment }\end{array}$} & Primary & $54 . \%(68)$ & $46.0 \%(58)$ & 126 & \multirow{4}{*}{$\begin{array}{l}\chi 2=0.55 \\
P=0.907\end{array}$} \\
\hline & Secondary & $61.1 \%(77)$ & $38.9 \%(49)$ & 126 & \\
\hline & Higher & $67.9 \%(110)$ & $32.1 \%(52)$ & 162 & \\
\hline & Never been to school & $83.3 \%(30)$ & $16.7 \%(6)$ & 36 & \\
\hline \multirow{4}{*}{$\begin{array}{l}\text { Mother's } \\
\text { level of } \\
\text { school } \\
\text { attainment }\end{array}$} & Primary & $67.5 \%(79)$ & $32.5 \%(38)$ & 117 & \multirow{4}{*}{$\begin{array}{l}\chi 2=1.52 \\
P=0.677\end{array}$} \\
\hline & Secondary & $55.6 \%(100)$ & $44.4 \%(80)$ & 180 & \\
\hline & Higher & $74.1 \%(80)$ & $25.9 \%(28)$ & 108 & \\
\hline & Never been to school & $57.8 \%(26)$ & $42.2 \%(19)$ & 45 & \\
\hline
\end{tabular}

Parental involvement was perceived the highest among children who lived with both parents with proportion of $68.9 \%(\mathrm{P}<0.05)$ and this was the only case were the association was significant.

Research hypotheses two: There is no significant relationship between parental involvement and academic performance of children with learning disabilities

Table 9: Perceived effect of parental involvement on academic performance

\begin{tabular}{|c|c|c|c|c|}
\hline & & & $\begin{array}{l}\text { Parental } \\
\text { involvement }\end{array}$ & $\begin{array}{l}\text { Academic } \\
\text { performance }\end{array}$ \\
\hline \multirow[t]{6}{*}{ Spearman's rho } & \multirow[t]{3}{*}{ Parental involvement } & $\begin{array}{l}\text { Correlation } \\
\text { Coefficient }\end{array}$ & 1.000 & .298 \\
\hline & & Sig. (2-tailed) & .2 & .038 \\
\hline & & $\mathrm{N} / \mathrm{D}$ & 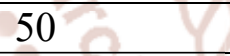 & 50 \\
\hline & \multirow{3}{*}{$\begin{array}{l}\text { Academic } \\
\text { performance ternat } \\
\text { of Tren }\end{array}$} & $\begin{array}{l}\text { Correlation } \\
\text { Coefficient }\end{array}$ & .298 & 1.000 \\
\hline & & Sig. (2-tailed) & .038 & \\
\hline & & $\mathrm{N}$ & 50 & 50 \\
\hline
\end{tabular}

*Correlation is significant at the 0.05 level . This means that the null hypotheses were rejected while the alternative hypotheses were retained. Parental involvement significantly contributed to improve the academic performance $(\mathrm{r}=-0.298 ; \mathrm{P}=0.038)$. Occupation was one of the main determinants of parental involvement besides level of education. This father for instance said he was always away because of his occupation and wife was the one supporting the child back home (No but wife attend since father is always away). This other father was builder and was always away and that reason paid less attention to the child (seldom when at home). This mother was a hair dresser and always come back home and could follow up her child and this particular child always stay away from school (No because I always come home late and have no time for my children).

Parents generally provide basic facilities like table and chair for the child to learn. Parents also attend PTA meeting and this gave them the opportunity to meet with teachers and discuss about the child (yes, give opportunity to meet with teachers and discussing children problems) or to contribute idea to the running of the school (Yes give correction and correct some ill-effects in school). As such, the alternative hypotheses were accepted and the null hypotheses rejected. Generally, parents appraise their support to the child through the academic performance of the child.

\section{Educational Implications of the Study}

From the findings, it is obvious that that home environment acts as a predictor for academic performance for children with learning disabilities. The implication of this is that though parents, teachers and state are aware about the importance of home environment as far as the education of children with learning disabilities is concerned some home factors like the socio-economic factors, parental involvement, parents level of education and home location of the pupils are factors to be looked in to when considering the academic performance of children with learning disabilities. 
This study has therefore contributed to the understanding of how important the home environment (conducive environment)is a predictor for academic performance for children with learning disabilities. Thus parents should make their homes places where their children can learnt. Analyses of the data collected in the study demonstrate that the role played by home environment in the education of children with learning disabilities is very vital and thus determine the academic performance of these children.

\section{Recommendations}

In light of the findings of this study, taking into consideration the results from the three selected schools, and in relevance to other schools in the country, when looking at children with learning disabilities, parents should yearn for higher educational qualification statuses since it will translate into better occupations and higher wages, that is higher socio-economic status, thus better educational choices and offerings can be provided for their children. Again, parents and all the significant others at home should make home environment to be learning stimulatory and study friendly for pupils. Further similar study may be replicated at any other level of Cameroon's educational system in any part of the country. It is also recommended that schools administrations should involve parents during teacher's seminars so that they will know how to better help their children at home.

It is recommended that to enable pupils with learning disabilities to be productive in society and become inclusive, all stakeholders must forge ahead to put forward policies and logistics towards gratifying the needs of pupils with learning disabilities.

Special teachers in the area of learning disabilities should be trained and recruited in schools so that these children can be given enough time and individualized teaching in their classrooms and follow up at home at home . In addition, enough learning tools such as text books good health care provisions both in schools and at home must be taken in to consideration.

From the study findings, it was realized that these pupils like any other normal child needs follow up after school to master skills but it should be noted that just as parents often help their gifted and average children to learn at home, most parents and caregivers are unable to read and cannot readily offer the same types of support at home to children with learning disabilities. Helping parents participate in their children's own reading and writing by encouraging them to be involved in their children education by helping them at home after school.

The government and other organisations in charge of the education of learners with learning disabilities should try to provide teachers with adequate instructional materials suitable for the adaptation to the varying needs of the learners for example text books, I T C braille.

Also, the government, and the educational system of Cameroon should come out with a standard learning grade that the learners must master to fully and effectively learn. The existing laws and policies in regard to the education of children with learning disabilities should also be reviewed in relation to the standards laid by the governing authorities.

\section{Conclusions}

The study sought to investigate home environment as a predictor of academic performance of children with learning disabilities. This study looked at how parental socio-economic status influence the academic performance of children with learning disabilities, the effect of parental involvement in the education of children with learning disabilities, the extent to which parental level of education influence the academic performance of children with learning disabilities, and also the effects of home location on the academic performance of children with learning disabilities. It was identify and established that the above variables affect the academic performance of children with learning disabilities, except in few cases where parental level of education had no greater influence. For this reason, home environment facts for should be highly considered as far as academic performance is concerned because there is no way a child can perform well in school without a good home environment.

\section{References}

1) Abosi,O.(2007).Educating children with Learning Disabilities in AfricaLearning Disabilities Research e practice,22,196-201

2) Amin, M. E. (2005). Social Science Research, Conception, Methodology and Analysis: Makerere University Printing. 
International Journal of Trend in Scientific Research and Development (IJTSRD) ISSN: 2456-6470

3) Azikwe,U.(2008). "Reforms in Educationand future of Nigeria sociological perspective" Nig.J.ofEdu.AndDevt.Studies(AJEDc),1(2);10-12.

4) Bandura, A. (1986). Social foundations of thought and action: A social cognitivetheoryEnglewood Cliffs, NJ: Prentice Hall.

5) Bandura A (1977) social Learning theoryEnglewodycliffs. $\mathrm{Nj}$;Prenice Hall.

6) BanduraA (1986) Social Foundations of thought and action; A social cognitive theoryPrenticeHall,Inc.

7) Bandura.A.Rose,D;\$

Ross, S.A(1961)transmission through the Imitation ofaggressive models.

8) Maslow, A. (1908-1700) Humanistic Theory

9) Boundless Psychology.boundless,08 Jan2016.Retrieved 18Feb.2016 from https. ॥ww.Boundless.Com $\backslash$ Psychology $\backslash$ test books $\backslash$ Boundless- Psychologytextbook $\backslash$ Personality $\backslash 78 \backslash$ Maslow's humanistictheory of personality-30712842.

10) Diaz,A.L.(2012)personal,family, and academic factors affecting low achievement in secondary school Electronic J.of Res.in Educational Psychology and Psychopedagogy,1(1),4366.ISBN 1696-2095

11) De Rose J, De Souza D.G, Hanna ES (1996): Teaching Reading and Spelling: Exclusion and Stimulus Equivalence.

12) Fitzgerald, J., \& Shanahan, T. (2000).Reading and writing relations and their development. Educational Psychologist, 35, 39-50.

13) Fraenkel, J. R., and Wallen, N.E. (2000).How to Design and Evaluate Research in Education $\left(4^{\text {th }}\right.$ Ed.) Boston: McGraw-Hill.

14) Freeman, K. F., O.D, (2007). Optometric clinical practice guideline: care of the patient with visual impairment

15) Glenna S. G. (2006): The Assistive Technology Skills, Knowledge, and Professional Development Needs of Special Educators in Southwestern Virginia. ...Place \& publisher.......

16) Grigorenko,E.L.(Ed)(2009).Multicultural Psychoeducational Assessment.New York; Springer Publishing Company
17) Hammill,D.D (1990). "On Defining Learning disabilities;An Emerging consensus." In Journal of Learning Disabilities, 23,74-84.

18) Hill

N.E.CastelinoO.R.LansforJ.E.NowlinE.DodgeP.B atesK.A.Pettit G.S.(2004).Parents Academic Involvement as Related to School Behavior.Achievement and Aspirations;Demographic Variations across Adolescence. Children development, Vol.75 (5),pp1491-1509

19) Deboratt Deutsch Smith, (Date).Introduction To Special Education Making a Difference Sixth Edition, Claremont Graduate University.

20) Katarynr.WentzelAssistant professor University of MaryLand,3304

Benjamin,Building,CollegePark,MD 20742,S H E

21) Kaufman, J. C., \& Gentile, C. A. (2002).The will, The wit, The judgment: The importance of an early start in productive and successful writing. High Ability Study

22) LD.onLine works in association with the National Joint Committee on Learning Disabilities(NJCLD).

23) Mbua, F.N. (2003). Educational Administration: Theories and Practice. The Management of Organisations and Individuals.Limbe: Pressprint.

24) Mclntosh,J.(2008)

background,parentalInvolvementand

"Family achievement" in academic Canadian schools.J.ofEcLit.classification Number 120J62.

25) Miller, R. (1997). What Are Schools For? Holistic EducationInAmerican Culture, $\quad 3^{\text {rd }}$ Edition. Brandon, VT: Holistic Education Press.

26) Nana,C. (2012). Research Methods and Applied Statistics: Beginners and advanced learners. Buea; GOAHEAD.

27) National Institute of Child Health and Human Development (2000). The Report of the National Reading Panel. Washington, D.C.: NICHD

28) National Institutes of Health, office of Science Education; http; \sscience-education.nih.gov

29) Ogbemudia,M.L.andAiasa,M.V.(2013) “Influence of home environment on the academic performance of primary five pupils in English Language" In OrhionmwonLocalGovernment 
International Journal of Trend in Scientific Research and Development (IJTSRD) ISSN: 2456-6470

Area of Edo stateMeritResJ.ofEd.and Rev, $1(5), 120-125$

30) No Child Left Behind Act of 2001: Public law print of P.L. No. 107-110. (2001). Retrieved fromhttp://www/ed.gov/policy/elsec/leg/esea02/in dex.html

31) Onen, D and Yoko W. (2008).A General Guidelines in Writing Research Proposals and Report ( $2^{\text {nd }}$ Ed.) Cambridge: Cambridge University Press.

32) Peter D. (2001): The Relevance of the Concept of Motivation to Human Performance Technology. (town\& Publisher)

33) PubMed.gov;Long-term Effects of parents education on children's Educational and Occupational success;Mediation by Family Interactions,Child Aggression, and Teenage Aspirations(town \& Publisher)

34) PubMed.gov; The Influence of Parent Education and Family Income on child Achievement; the indirect Role of Parental Expectations and the home Environment(town \& Publisher)

35) Steve, G.(2003). "Want to Improve Children's Writing? Don't Neglect their Handwriting." In American Educator 33, no. 4 (town \& Publisher)

36) Texas National Agenda for Education of Children and Youth with Visual Impairment School (1986). (uncompleted)

37) United State Government Accountability Office (2007).(uncompleted)

38) Vygotsky, Lev(1978). "Minding society" In Journal of Abnormal and social Psychology'63,575-582..London;Harvard

University press.Copyright 201612 manage-The Executive Fast Track.V14.0-Last Updated'12-72016.All names tm by their owners.(Page x..... nber and volume?)

39) Ajila C. \&OututolaA. (2000). "Impact of parents socio-economic status on University Students Academic performance"In Life Journal of Educational studies, Volume75(5,)pp14911509(town \& Publisher)

40) Anene G .U.(2005). "Home Environment and the Academic performance of a child", In Journal of
Home Economics Research,Vol.6(1).pp.99100.(town\& Publisher)

41) Nanalee C. (1997). Youngliving $\quad\left(7^{\text {th }}\right.$ edition).McGraw Hill.New York.

42) Chaiklin,S.(2003). "The zone of proximal development in Vygotsky;s theory of learning and school instruction".InEducational theory in cultural context,Kozulin,A.,Gindis,B.Ageyev,V.S and

Miller,S.M.eds.Vygotsky's.Cambridge;Cambridge University press, 39 64.http;dx.do.org|10.1017|CBO978051140975.00 4

43) Lui,C.H.\&Mathews,R(2005).Vygotsky'sPhilophy. Constructivism and its criticism examined.(town \& Publisher)

44) International Educational Journal,6(3).386-399 Rogoff,B.(1990).“Apprenticeship

in thinking.Cognitive development in the social context". In OxfordUniversity press Journal of Abnormal and Social Psychology,63,575582.(town\& Publisher)

45) Sirin,S.R.(2005) Socio-economic status and academic achievement; A meta-Analytic Review of Educational Research,75(3),417-453(town \& Publisher)

46) Chopra(1964), "A study of Relationship of socioeconomic factors with environments of the students in the secondary schools" In Doctoral dissertation, Lucknow University,(Page, Volume, no?)

47) Goswami.R.(1982). "An Enquiry into ready Interests of the pupils of standard V11 to Xin Relation to intelligence", SES and Academic, Achievement

Dissertation.M.S.University Baroda(Page,

Volume, no?)

48) Rothman's (2003), “The changing influence of socioeconomic status on students academic achievement", In Recent evidence from Australia p,151 paper presented at the annual meeting of the American education Research Association, Chicago, April 2003 